\title{
Molecular biology of gonadotrophins
}

\author{
D. L. Hamernik ${ }^{*}$ \\ Department of Veterinary and Biomedical Science, University of Nebraska-Lincoln, \\ PO Box 830905, Lincoln, NE 68583-0905, USA
}

\begin{abstract}
Regulation of gonadotrophin synthesis involves a complex interaction between hypothalamic and gonadal hormones. Chronic administration of oestrogens and androgens to gonadectomized animals blocked the postcastration rise in amounts of mRNA encoding gonadotrophin subunits. Removal of endogenous GnRH decreased amounts of mRNA encoding gonadotrophin subunits. Pulsatile administration of GnRH to GnRH-deficient animals increased amounts of mRNA encoding gonadotrophin subunits. Studies using transgenic mice and transient transfection assays identified at least eight cis-acting DNA sequences in the proximal $350 \mathrm{bp}$ of $5^{\prime}$ flanking sequence of the human $\alpha$ subunit gene that directed expression to gonadotrophs or conferred responsiveness to oestrogens, androgens or $\mathrm{GnRH}$. Unique DNA-binding proteins were also identified which directed expression of the human $\alpha$ subunit gene specifically to the pituitary. Pituitary cell lines that express bovine gonadotrophin subunit genes are not currently available; thus, relatively little is known about the molecular mechanisms that regulate expression of bovine gonadotrophin subunit genes. Recent studies with transgenic mice harbouring bovine $\alpha$, LH $\beta$, or FSH $\beta$ subunit transgenes revealed that DNA sequences important for gonadotroph-specific expression and hormonal regulation resided within the proximal $5^{\prime}$ flanking sequences.
\end{abstract}

\section{Introduction}

Reproduction in mammals depends on synthesis and secretion of gonadotrophins (LH and FSH) from the anterior pituitary gland. LH and FSH stimulate steroidogenesis and gametogenesis in males and females, and are members of the glycoprotein hormone family that also includes the pituitary hormone TSH. Syncytiotrophoblasts of primates and horses produce a fourth glycoprotein hormone, chorionic gonadotrophin (CG). Glycoprotein hormones consist of a common $\alpha$, subunit and a hormone-specific $\beta$ subunit that confers biological specificity (Pierce and Parsons, 1981). Whereas pituitary gonadotrophin subunits are encoded by single-copy genes located on different chromosomes, there are six CG $\beta$ subunit genes arranged in a cluster that spans approximately $50 \mathrm{~kb}$ in humans (Jameson and Hollenberg, 1993). The $\alpha$ subunit gene is unique because it is expressed in the pituitary gland of all mammals and in the placenta of primates and horses. Recently, CDNA and genomic clones for gonadotrophin subunits have been characterized from a number of species including cattle (reviewed by Gharib et al, 1990).

Synthesis of gonadotrophins in the pituitary is thought to occur in a manner similar to that described for other glycoproteins (Chappel et al., 1983). In general, gonadotrophin genes are transcribed in the nucleus to yield specific mRNA molecules that are processed (i.e. addition of the $5^{t}$ CAP structure, splicing of intervening nucleotide sequences and addition of the $3^{\prime}$ poly $A$ tail) and transported to the cytoplasm where translation of mRNA to protein occurs on ribosomes. Further processing occurs on ribosomes and in the endoplasmic reticulum and involves removal of the signal peptide and 
glycosylation. Additional modifications of carbohydrate moieties occur in the Golgi apparatus. Newly synthesized proteins are stored in secretory granules (Chappel et al., 1983). Although each of these steps is a potential site of quantitative or qualitative regulation, this review will focus on pretranslational regulation of gonadotrophin synthesis in ruminants. Additional details of regulated expression of gonadotrophin genes in rodents and humans will be presented when such information in ruminants is lacking.

\section{Regulation of Amounts of mRNA Encoding Gonadotrophin Subunits}

Although much was known about regulation of gonadotrophin secretion, only in the last ten years have significant strides been made in understanding regulation of gonadotrophin synthesis. In most physiological situations, amounts of mRNA encoding gonadotrophin subunits are coordinately regulated. In general, expression of gonadotrophin subunit genes is enhanced by $\mathrm{GnRH}$ and inhibited by chronic administration of gonadal steroids or inhibin (reviewed by Gharib et al., 1990; Mercer, 1990; Nett, 1990).

Amounts of mRNA encoding gonadotrophins change during the ovine oestrous cycle and during pregnancy and the early postpartum period in sheep (Nett, 1990). However, not all periods of anoestrus are characterized by insufficient amounts of mRNA encoding gonadotrophin subunits. Steady-state amounts of mRNA encoding $\alpha$ and LH $\beta$ subunits are not limiting during sexual maturation in beef heifers (Roberson et al., 1992). Changes in amounts of mRNA encoding gonadotrophin during the ovine oestrous cycle and pregnancy may result from changes in serum concentrations of gonadal steroids or changes in pulsatile secretion of GnRH.

\section{Regulation of $m R N A$ encoding gonadotrophin subunits by ovarian steroids and GnRH}

After ovariectomy there is a gradual increase in amounts of mRNA encoding gonadotrophin subunits in the pituitary (Gharib et al., 1990). Chronic administration of oestradiol to ovariectomized ewes decreased amounts of mRNA encoding gonadotrophin subunits, while chronic administration of midluteal phase concentrations of progesterone did not affect amounts of mRNA encoding gonadotrophin subunits (Gharib et al., 1990; Mercer, 1990; Nett, 1990). Studies with at least three different experimental models revealed that oestradiol and progesterone acted directly at the anterior pituitary gland to regulate amounts of mRNA encoding gonadotrophin subunits. In primary cultures of sheep pituitaries, oestradiol or progesterone inhibited steady-state amounts of mRNA encoding $\alpha$ and FSH $\beta$ subunits (Phillips et al., 1988). Treatment of ovariectomized and hypothalamic-pituitary disconnected ewes with pulsatile administration of $\mathrm{GnRH}$ and chronic administration of oestradiol demonstrated that oestradiol acted directly at the anterior pituitary to regulate amounts of mRNA encoding FSH $\beta$ subunit negatively and positively regulate amounts of mRNA encoding $\alpha$ subunit without affecting amounts of mRNA encoding LH $\beta$ subunit (Mercer et al., 1988, 1989). In contrast, Nett et al. (1990) administered oestradiol and progesterone to ovariectomized ewes for 69 days and then gave pulsatile GnRH for an additional 42 days. Pulses of exogenous GnRH did not increase amounts of mRNA encoding $\alpha$ or LH $\beta$ subunits. Thus, oestradiol and progesterone inhibited amounts of mRNA encoding $\alpha$ and LH $\beta$ subunits by acting directly at the anterior pituitary gland,

Because oestradiol and progesterone acted at the hypothalamus to decrease secretion of GnRH in sheep (Karsch et al., 1987), it is possible that ovarian steroids regulated amounts of mRNA encoding gonadotrophin subunits indirectly by inhibiting secretion of $\mathrm{GnRH}$ which was needed to stimulate gonadotrophin synthesis. Relative amounts of mRNA encoding gonadotrophin subunits decreased after removal of endogenous GnRH by hypothalamic-pituitary disconnection in ovariectomized ewes (Hamernik et al., 1986; Mercer et al., 1988). Administration of a GnRH antagonist, which occupied GnRH receptors and prevented endogenous GnRH from stimulating gonadotrophs, decreased amounts of mRNA encoding gonadotrophin subunits in ovariectomized ewes (Sanchez et al., 1994). Immunoneutralization of endogenous GnRH by active immunization of ovariectomized beef cows to $\mathrm{GnRH}$ also resulted in decreased amounts of mRNA encoding $\alpha$ and LH $\beta$ subunits (Stumpf et al., 1992). Hence, 
ovarian steroids regulated amounts of mRNA encoding gonadotrophin subunits both by acting directly at the anterior pituitary gland and by acting indirectly at the hypothalamus to decrease secretion of $\mathrm{GnRH}$, which is required to stimulate amounts of mRNA encoding gonadotrophin subunits.

\section{Regulation of mRNA encoding gonadotrophin subunits by androgens}

In contrast to inhibitory effects of oestradiol and progesterone on mRNA encoding gonadotrophin subunits, androgens negatively regulated only mRNA encoding $\alpha$ and LH $\beta$ subunits and had little or no effect on mRNA encoding FSH $\beta$ subunit in male rodents (Gharib et al., 1990). In another study, androgen stimulated mRNA encoding FSH $\beta$ subunit but decreased mRNA encoding $\alpha$ and LH $\beta$ subunits in castrate male rats treated with a GnRH antagonist (Wierman and Wang, 1990). Thus, androgen could potentially act directly at the anterior pituitary gland to positively regulate amounts of mRNA encoding FSH $\beta$ subunit. Although regulation of gonadotrophin gene expression in male ruminants has not been extensively characterized, it seems likely that androgens may act directly at the anterior pituitary gland, as well as indirectly at the hypothalamus to control synthesis of gonadotrophins.

\section{Regulation of mRNA encoding gonadotrophin subunits by gonadal polypeptides}

Production of polypeptides (inhibin, activin, follistatin) by developing ovarian follicles during late dioestrus and the preovulatory period provides a mechanism for differential control of LH and FSH synthesis and secretion. Administration of charcoal-stripped follicular fluid (containing inhibin) to ovariectomized heifers (Beard et al., 1989) and ewes (Mercer et al., 1987; Nett, 1990) specifically decreased mRNA encoding FSH $\beta$ subunit, but not mRNA encoding $\alpha$ or LH $\beta$ subunits. Likewise, inhibin decreased amounts of mRNA encoding FSH $\beta$ subunit, but not mRNA encoding $\alpha$ or LH $\beta$ subunits in ovariectomized ewes that received pulsatile GnRH after hypothalamic-pituitary disconnection (Mercer et al., 1987). Purified porcine inhibin also decreased amounts of mRNA encoding FSH $\beta$ subunit in primary cultures of rat pituitaries (Gharib et al., 1990). Thus, inhibin acted directly at the anterior pituitary gland to suppress amounts of mRNA encoding FSH $\beta$ subunit specifically.

In primary cultures of rat pituitaries, activin stimulated amounts of mRNA encoding FSH $\beta$ subunit but did not affect amounts of mRNA encoding $\alpha$ or LH $\beta$ subunits (Gharib et al, 1990). Follistatin was identified in ovarian follicular fluid and may regulate synthesis of FSH by binding activin to prevent activin from stimulating production of FSH (Findlay, 1993). Administration of purified porcine follistatin to primary cultures of rat pituitaries decreased amounts of mRNA encoding FSH $\beta$ subunit but did not affect amounts of mRNA encoding $\alpha$ or LH $\beta$ subunits (Gharib et al., 1990). In addition to ovarian follicles, rodent and primate gonadotrophs were also a source of activin and follistatin (Roberts et al., 1989; Attardi et al., 1992; Bilezikjian et al., 1993; DePaolo et al., 1993). Thus, activin and follistatin may regulate amounts of mRNA encoding FSHB subunit by paracrine actions.

\section{Iranscriptional and post-transcriptional regulation of gonadotrophin synthesis}

The aforementioned studies described measurements of steady-state amounts of mRNA encoding gonadotrophins in various physiological states. The limitation to these studies was that transcriptional and post-transcriptional regulation of gonadotrophin synthesis was not investigated directly. Transcriptional regulation of gonadotrophin subunit genes was studied further by isolating nuclei from pituitaries and conducting nuclear run-off assays to measure rates of transcription directly. Estimates of gonadotrophin mRNA stability were determined by measuring RNA turnover in the presence of drugs that block synthesis of RNA.

Transcriptional and post-transcriptional regulation of gonadotrophins by gonadal steroids. Chronic administration of oestradiol to ovariectomized rats inhibited transcription of gonadotrophin genes in vivo (Gharib et al., 1990). Administration of oestradiol or progesterone to ovine pituitary cells in vitro inhibited transcription of $\alpha$ and FSH $\beta$ subunit genes (Phillips et al, 1988). Transcription of $\alpha$ and 
LH $\beta$ subunit genes was reduced by administration of testosterone to castrate male rats (Paul et al., 1990). However, stimulatory effects of testosterone on amounts of mRNA encoding FSH $\beta$ subunit in castrate male rats did not involve increased transcription of the gene encoding FSH $\beta$ subunit and probably resulted from increased stability of mRNA encoding FSH $\beta$ subunit (Paul et al., 1990). Thus, gonadal steroids acted directly at the anterior pituitary gland to regulate transcription of gonadotrophin subunit genes and stability of mRNA encoding gonadotrophin.

Transcriptional and post-transcriptional regulation of gonadotrophins by $\mathrm{GnRH}$. Pulsatile administration of GnRH stimulated transcription of genes encoding $\alpha, \mathrm{LH} \beta$ and FSH $\beta$ subunits in rat pituitaries in vitro (Gharib et al., 1990). Administration of a GnRH antagonist to castrate male rats inhibited rates of transcription of $\alpha$, LH $\beta$ and FSH $\beta$ subunit genes ( $P$ aul et al, 1990). A mouse gonadotroph cell line ( $\alpha$ T3- 1 cells) that expresses the endogenous $\alpha$ subunit gene and GnRH receptors was developed by Windle et al. (1990). The $\alpha \mathrm{T} 3-1$ cells do not express LH $\beta, F S H \beta$ or TSH $\beta$ subunit genes or TRH receptors (Windle et al., 1990). Rates of transcription and stability of mRNA encoding $\alpha$ subunit was stimulated by $\mathrm{GnRH}$ in $\alpha \mathrm{T} 3-1$ cells (Chedrese et al, 1994). Effects of GnRH on stability of mRNA encoding gonadotrophin subunits have not yet been investigated in vioo. Thus, $\mathrm{GnRH}$ stimulated gonadotrophin synthesis in vivo by increased rates of transcription of gonadotrophin subunit genes and increased stability of mRNA encoding gonadotrophin subunits.

Transcriptional and post-transcriptional regulation of gonadotrophins by gonadal polypeptides. Inhibin decreased the rate of transcription of the FSH $\beta$ subunit gene, in sheep; however, post-transcriptional mechanisms may also be required to account fully for the suppressive effects of inhibin on amounts of mRNA encoding FSH $\beta$ subunit (Clarke et al., 1993). Inhibin or follistatin reduced steady-state amounts of mRNA encoding FSH $\beta$ subunit in primary cultures of rat pituitaries by increased degradation of mRNA encoding FSH $\beta$ subunit (Attardi and Winters, 1993). Thus, effects of gonadal peptides on mRNA encoding FSH $\beta$ subunits appear to be regulated primarily by post-transcriptional processes, In summary, $\mathrm{GnRH}$ and gonadal hormones regulate amounts of mRNA encoding gonadotrophin subunits by altering rates of transcription of gonadotrophin subunit genes and by influencing stability of mRNA encoding gonadotrophin subunits.

\section{Characterization of $\mathrm{C}$ is-acting DNA Sequences and Trans-acting DNA Binding Proteins that Regulate Transcription of Genes Encoding Gonadotrophins}

Identification of cis-acting regulatory DNA sequences, trans-acting nuclear transcription factors and the mechanisms regulating expression of genes in specific cells or in response to extracellular signals has been the focus of work in several laboratories in recent years. The general scheme for these studies involves (i) isolation of putative regulatory regions, (ii) modification of native DNA sequences (i.e. mutations or deletions), (iii) construction of chimaeric genes by linking the putative regulatory regions to reporter genes, (iv) transfer of chimaeric genes into cells in culture (i.e. transient transfection assays) or into the mouse genome (i.e. transgenic mice), and (v) assay of reporter gene activity as a measure of promoter function.

Transient transfection of mouse or human $\alpha$ subunit promoters in $\alpha$ T3-I cells or production of transgenic mice harbouring rat, bovine or human gonadotrophin $\alpha$ and $\beta$ subunit genes were used to identify promoter-regulatory sequences (necessary for the correct start site of transcription) and enhancer sequences (important for quantitative changes in transcription). Our current understanding of the cis-acting DNA sequences important for gonadotroph-specific expression and hormonal regulation of genes encoding gonadotrophin subunits are shown in Fig. 1. Much of what is known about the DNA regulatory sequences and DNA binding proteins important for transcription of the $\alpha$ subunit gene was obtained by transient transfection of the human $\alpha$ subunit $5^{\prime}$ flanking region linked to the bacterial gene encoding chloramphenicol acetyltransferase (CAT) into $\alpha \mathrm{T} 3-1$ cells or human choriocarcinoma cells (cell lines of human placental origin that express endogenous $\alpha$ and CG $\beta$ subunit genes). 


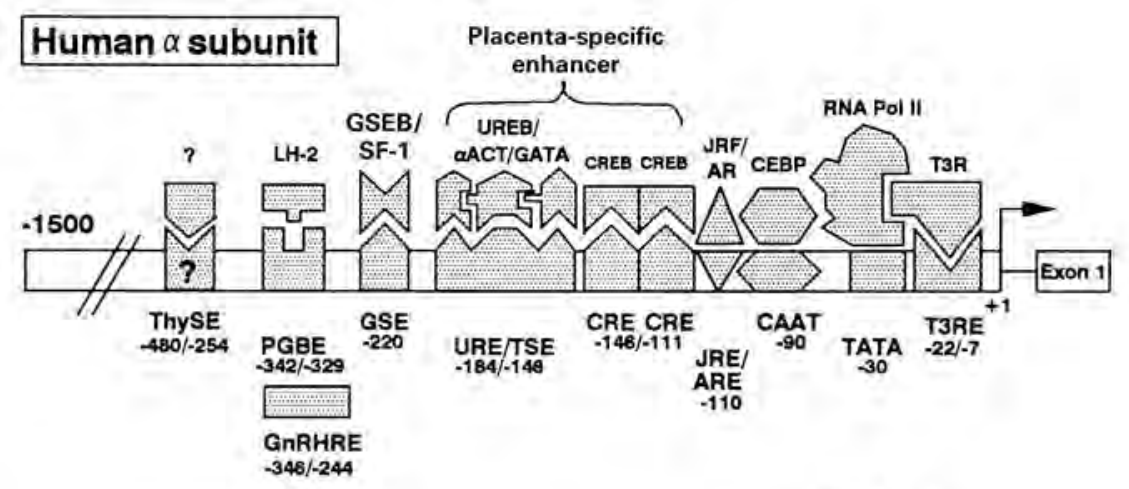

\section{Bovine $\alpha$ subunit}

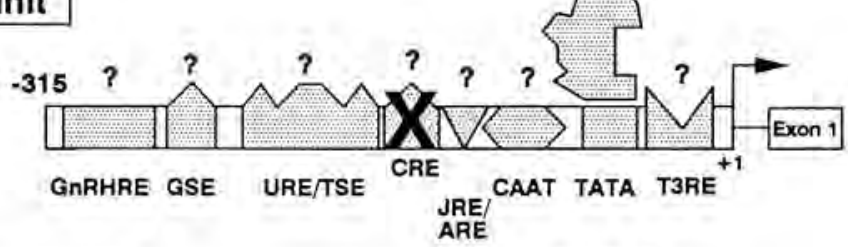

\section{Bovine LH $\beta$ subunit}
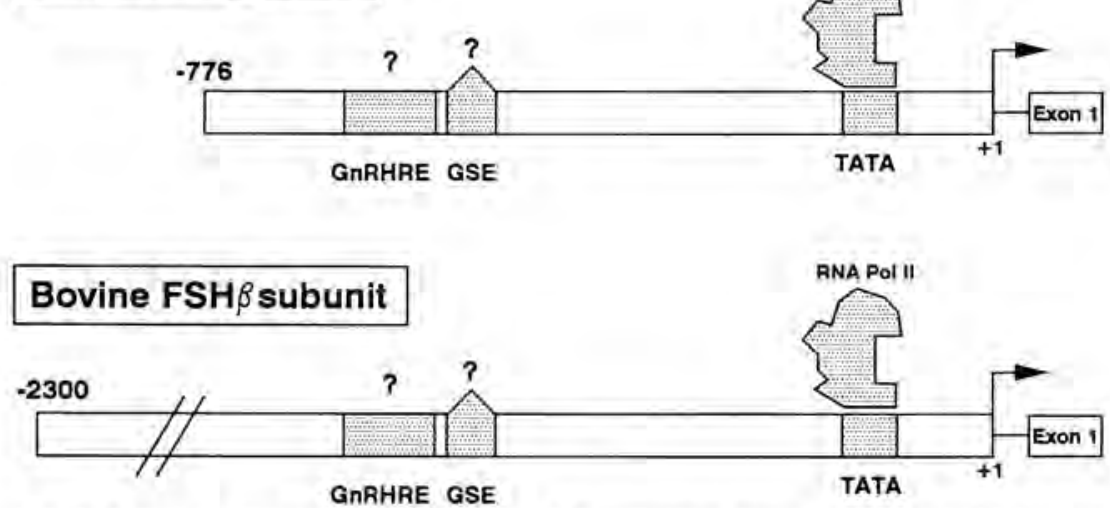

Fig. 1. A model describing the cis-acting DNA sequences and frans-acting DNA-binding proteins that regulate expression of gonadotrophin subunit genes. Expression of the human $\alpha$ subunit gene requires the following: (i) TATA sequence and the RNA polymerase II complex of transcription factors (RNA Pol II), (ii) CAAT sequence and CAAT enhancer binding protein (CEBP), (iii) the junctional regulatory element (JRE) and JRE binding factor (JRF) in placenta or androgen response element (ARE) and androgen receptor (AR) in pituitary, (iv) tandem CAMP response elements (CRE) and CRE binding protein (CREB), (v) the upstream regulatory element (URE) or trophoblast-specific element (TSE) and URE binding proteins (UREB, $\alpha A C T$ or GATA binding proteins), (vi) a gonadotroph-specific element (GSE) and GSE-binding protein (GSEB or steroidogenic factor I, SF-I), (vii) a pituitary glycoprotein hormone basal element (PGBE) and LIM-homeodomain transcription factor 2 ( $\mathrm{LH}-2$ ), and (viii) a GnRH responsive element (GnRHRE). The thyroid hormone response element (T3RE) binds thyroid hormone-thyroid hormone receptor complex (T3R) and represses transcription by preventing binding of RNA polymerase II to the human $\alpha$ subunit gene in vitro. A thyrotroph-specific element (ThySE) was defined in vitro but was not functional in transgenic mice. The bovine $\alpha$ subunit gene lacks a functional CRE and shares nucleotide sequence similarity with several regulatory sequences in the human $\alpha$ subunit gene; however, it is not yet known whether these sequences are functional in the bovine $\alpha$ subunit gene. Functional cis-acting regulatory sequences have not yet been reported in the bovine gonadotrophin $\beta$ subunit genes. The arrow indicates the transcription initiation site $(+1)$. 
The minimal DNA sequences needed for expression of the human $\alpha$ subunit gene in placenta are located within the proximal $169 \mathrm{bp}$ of $5^{\prime}$ flanking sequence and consist of (i) the TATA sequence that binds the RNA polymerase II complex of transcription factors to initiate transcription correctly (ii) a CAAT sequence that binds a placenta-specific member of the ubiquitous CCAAT enhancer binding protein (CEBP) family (Kennedy et al., 1990), (iii) a junctional regulatory element (JRE) which binds a specific protein in placenta (junctional regulatory factor, JRF; Andersen et al, 1990) or the androgen receptor in the pituitary (Clay ef al., 1993), (iv) two copies of a consensus cAMP response element (CRE) which bind the ubiquitous CRE binding protein (CREB) and confers responsiveness to activators of protein kinase $A$ and $C$ pathways (reviewed by Jameson and Hollenberg, 1993) and (v) an upstream regulatory element (URE) or trophoblast-specific element (TSE) which binds placenta-specific proteins (Jameson and Hollenberg, 1993; Steger et al,, 1993; Pittman et al., 1994; Steger et al, 1994). Sequences important for gonadotroph-specific expression (GSE) are discussed in detail below. A thyroid hormone responsive element (T3RE) is located near the transcription initiation site and, when bound by thyroid hormone-thyroid hormone receptor complex, represses transcription by preventing binding of RNA polymerase II (Chatterjee et al, 1989). A DNA sequence important for expression of the human or mouse a subunit promoters in thyrotrophs (ThySE) was reported from studies in vitro (Ocran et al., 1990; Sarapura et al., 1990) but was not functional in transgenic mice (Hamernik et al., 1992). The discrepancy between transfection analyses and studies with transgenic mice are intriguing and may result from more rigid requirements for correct cell-specific expression of the transgene during development in transgenic mice.

Pituitary cell lines that express bovine or ovine gonadotrophin subunit genes are not yet available; thus, much less is known about cis-acting DNA sequences and trans-acting DNA binding proteins that regulate expression of bovine or ovine gonadotrophin subunit genes. Human and bovine $\alpha$ subunit genes share approximately $85 \%$ identity in nucleotide sequence within the proximal 315 bp of $5^{\prime}$ flanking sequence (Bokar et al., 1989). Thus, it seems likely that the TATA, T3RE, CAAT, JRE, URE and GSE sequences are functional in the bovine $\alpha$ subunit promoter. In summary, the human $\alpha$ subunit gene contains DNA sequences that are (i) common to many other eukaryotic genes (i.e. TATA and CAAT), (ii) unique to genes expressed in gonadotrophs (i.e. GSE), and (iii) important for hormonal regulation (i.e. CRE, T3RE and JRE).

\section{Gonadotroph-specific expression}

Gonadotrophin $\beta$ subunit genes are expressed solely in gonadotrophs, while the common $\alpha$ subunit gene is expressed in gonadotrophs and thyrotrophs in the anterior pituitary gland of all mammals. Studies with transient transfection of the human or mouse $\alpha$ subunit promoters into $\alpha$ T $3-1$ cells have recently identified enhancer sequences and DNA-binding proteins that are important for expression of a. subunit in gonadotrophs. DNA sequences approximately $340 \mathrm{bp}$ upstream of the transcriptional start site in the mouse $\alpha$ subunit promoter are important for expression of the mouse $\alpha$ subunit promoter in gonadotrophs and thyrotrophs (Schoderbek et al., 1992). This DNA sequence is important for basal expression of the mouse $\alpha$ subunit gene in the pituitary and was designated the pituitary glycoprotein hormone basal element (PGBE; Roberson et al., 1994). A transcription factor of the LIM*-homeodomain family, $\mathrm{LH}-2$, bound specifically to the PGBE and stimulated expression of the mouse $\alpha$ subunit gene in gonadotrophs and thyrotrophs (Roberson et al., 1994). A gonadotroph-specific element (GSE) approximately 220 bp upstream of the transcription initiation site that bound a protein unique to gonadotrophs (gonadotroph-specific element binding protein, GSEB) was also reported by Horn et al. (1992). GSEB was shown to be the orphan nuclear receptor steroidogenic factor-1 (SF-1), which is a primary regulator of genes encoding steroidogenic enzymes in the adrenal gland and gonads (Barnhart and Mellon, 1994). DNA-binding proteins of the GATA family bound to specific DNA sequences in the URE and may be important for expression of $\alpha$ subunit in the pituitary (Steger et al., 1994). Thus, expression of the human $\alpha$ subunit gene in the pituitary requires several specific DNA sequences (i.e. PGBE, GSE and URE) and unique DNA-binding proteins (i.e. LH-2, GSEB/SF-1 and GATA binding proteins).

${ }^{\prime}$.IM is an acronym for $\lim -11$, is $/-1$, and mec-3. These genes encode proteins that share structural similarities in a region called the LIM domain. The LIM domain comprises putative zinc finger-like structures and regulates transcription by participating in protein-protein interactions. 
A transgenic mouse model was developed to investigate further the regulated expression of the human or bovine $\alpha$ subunit promoters in a physiological setting. The transgenic mouse model was important because the bovine $\alpha$ subunit promoter was not expressed after transient transfection in $\alpha$ T3-I cells. In transgenic mice, pituitary-specific expression was directed by about 1500 bp of human or 315 bp of bovine $\alpha$ subunit 5' flanking sequence (Bokar et al., 1989). These findings were significant because they narrowed the location of important regulatory sequences in an $\alpha$ subunit genomic clone of approximately $17 \mathrm{~kb}$ to only $1500 \mathrm{bp}$ of human or $315 \mathrm{bp}$ of bovine $\alpha$ subunit $5^{\prime}$ flanking sequence. Hamernik et al. (1992) used gonadectomy and hormone-replacement paradigms and found that $1500 \mathrm{bp}$ of human and $315 \mathrm{bp}$ of bovine $\alpha$ subunit $5^{\prime}$ flanking sequence directed expression specifically to gonadotrophs in transgenic mice. We subsequently constructed a second line of transgenic mice that harboured $1500 \mathrm{bp}$ of the human $\alpha$ subunit gene linked to the bacterial lac Z gene (encoding $\beta$-galactosidase) to directly test for cell-specific expression of the human $\alpha$ subunit promoter. Colocalization studies were conducted by staining cross-sections of pituitaries from transgenic mice for $\beta$-galactosidase and performing immunocytochemistry with antibodies to either LH or TSH to identify gonadotrophs or thyrotrophs, respectively, that express the human $\alpha$ subunit transgene. Consistent with our hormone-replacement paradigms, cell-specific staining in pituitaries of transgenic mice revealed that the human $\alpha$ subunit promoter was expressed in gonadotrophs, but not in thyrotrophs (Hamernik et al., 1992). Another line of transgenic mice containing the bovine $\alpha$ subunit promoter linked to the diphtheria toxin A-chain structural gene demonstrated severe hypogonadal phenotype owing to almost complete ablation of gonadotrophs; other cell types in the anterior pituitary, including thyrotrophs, were normal (Kendall ef al., 1991). Collectively, our studies with transgenic mice demonstrated that the proximal $1500 \mathrm{bp}$ of human or $315 \mathrm{bp}$ of bovine $\alpha$ subunit $5^{\prime}$ flanking sequence contained enough information to direct expression specifically to gonadotrophs in transgenic mice.

Compared with $\alpha$ subunit, relatively little is known about the molecular mechanisms underlying gonadotroph-specific expression of gonadotrophin $\beta$ subunit genes. Lack of gonadotroph cell lines that express gonadotrophin $\beta$ subunits has limited progress in this area. To begin to investigate regulated expression of the LH $\beta$ subunit gene, Kim et al. (1990) transiently transfected $1.7 \mathrm{~kb}$ of $5^{\prime}$ flanking sequence of the rat LH $\beta$ subunit gene and found promoter activity in primary cultures of rat pituitary cells but not in human choriocarcinoma cells or $\mathrm{GH}_{3}$ cells (growth hormone and prolactin producing cells). Transgenic mice have recently been constructed that contain about $2 \mathrm{~kb}$ of rat, $1.9 \mathrm{~kb}$ of ovine, or 776 bp of bovine LH $\beta$ subunit 5' flanking sequence (Fallest and Shupnik, 1994; Brown et al., 1993; Keri et al., 1994, respectively). The $L H \beta$ subunit promoter directed expression to gonadotrophs in all lines of transgenic mice. Assuming that mechanisms underlying gonadotroph-specific expression are conserved across species, then sequences necessary for gonadotroph-specific expression must reside within the proximal $776 \mathrm{bp}$ of $5^{\prime}$ flanking sequence of the LHß subunit gene. Using $2.3 \mathrm{~kb}$ of bovine FSH $\beta$ subunit $5^{\prime}$ flanking sequence, Markkula et al. (1993) reported expression of the transgene in the pituitary and testis of transgenic mice. It seems likely that gonadotrophin $\beta$ subunit genes may contain DNA sequences similar to those found in $\alpha$ subunit that direct expression specifically to gonadotrophs (i.e. GSE). Additional studies using transgenic mice or transient transfection assays in cell lines that express gonadotrophin $\beta$ subunit genes with mutations in the gonadotrophin $\beta$ subunit promoters will be required to define more precisely cis-acting DNA sequences and DNA-binding proteins directing expression of gonadotrophin $\beta$ subunit genes to gonadotrophs.

\section{Oestrogen-responsive DNA sequences}

Chronic administration of oestradiol to ovariectomized animals decreased the amounts of mRNA encoding gonadotrophin subunits (Gharib et al, 1990; Mercer, 1990; Nett, 1990). However, the molecular mechanisms through which oestradiol inhibited transcription of gonadotrophin subunit genes have not been well understood. In general, steroid hormones regulate transcription by binding to nuclear receptors to form steroid hormone receptor complexes that interact with specific DNA sequences. The highly conserved oestrogen responsive element (ERE) consists of the sequence: AGGTCAnnnTGACCT (where $n$ is any nucleotide) and binds the purified oestrogen receptor complex with high affinity (Beato, 1989). The human $\alpha$ subunit gene lacks a high-affinity binding site for the oestrogen receptor (Keri et al., 
1991). In addition, oestradiol failed to regulate $1500 \mathrm{bp}$ of the human $\alpha$ subunit $5^{\prime}$ flanking sequence following transient transfection in cells that contain endogenous oestrogen receptor (MCF-7 cells, a human breast tumour cell line) or lack endogenous oestrogen receptor (BeWo, human choriocarcinoma cells; Keri et al., 1991). Adult female transgenic mice were ovariectomized and treated chronically with oestradiol for 2 weeks to determine whether the $5^{\prime}$ flanking regions of the human or bovine $\alpha$ subunit genes were responsive to oestradiol. Activity of human or bovine $\alpha$ subunit promoters was inhibited approximately $75 \%$ in pituitaries of oestradiol-treated transgenic mice (Keri et al., 1991). From these studies, it was concluded that oestradiol regulated expression of the $\alpha$, subunit gene by a mechanism that did not involve direct binding of the oestrogen receptor complex to the $\alpha$ subunit gene. The indirect mechanism whereby oestradiol regulated expression of the $\alpha$ subunit gene probably involved altered secretion of GnRH (see discussion below).

In contrast to the $\alpha$ subunit gene, a high-affinity binding site for the oestrogen receptor complex was found in the rat LH $\beta$ subunit gene. A DNA sequence that was similar to the consensus ERE described above was localized between 1388 and 1105 bp upstream of the transcription initiation site in the rat LH $\beta$ subunit gene (Shupnik et al., 1989). Surprisingly, oestradiol stimulated (rather than inhibited) transcription of the rat LH $\beta$ subunit promoter following transient transfection into $\mathrm{GH}_{3}$ cells (Shupnik et al., 1989). In transgenic mice expressing the rat or bovine LH $\beta$ subunit transgenes in the pituitary chronic administration of oestradiol to gonadectomized animals reduced activity of the LH $\beta$ subunit promoter to values comparable to those of intact animals (Fallest and Shupnik, 1994; Keri et al., 1994). Thus, oestradiol could potentially regulate transcription of the LH $\beta$ subunit gene by a direct stimulatory action or an indirect inhibitory action that involves decreased secretion of GnRH from the hypothalamus.

\section{Androgen-responsive DNA sequences}

Like oestrogens, chronic administration of testicular androgens to castrated animals suppressed amounts of $\alpha$ and LH $\beta$ subunit mRNA (Gharib et al., 1990), However, the molecular mechanisms through which androgens inhibit expression of gonadotrophin subunit genes appear to be distinct from those of oestrogen. Whereas the oestrogen receptor complex failed to bind directly to the human $\alpha$ subunit gene (Keri et al., 1991), androgen receptor complex bound with high affinity to the human $\alpha$ subunit promoter and inhibited transcription of the human $\alpha$ subunit promoter after transient transfection in $\alpha \mathrm{T} 3-1$ cells (Clay et al., 1993).

The first indication that human and bovine $\alpha$ subunit $5^{\prime}$ flanking sequences might be regulated by androgen directly was the presence of a region similar to the consensus androgen response element (ARE; GGTACAnnnTGTTCT; Beato, 1989) about 101 bp upstream of the transcription initiation site. This region was previously defined as the JRE (Andersen et al., 1990). Gel-mobility shift assays were subsequently conducted to demonstrate that the JRE/ARE in the human $\alpha$ subunit promoter bound purified androgen receptor with high affinity in vitro (Clay et al., 1993). The functional importance of the JRE/ARE in conferring transcriptional repression to the human a subunit gene was demonstrated by cotransfecting the human $\alpha$ subunit promoter with human androgen receptor expression vector in $\alpha \mathrm{T} 3-1$ cells (Clay et al., 1993). In addition, chronic administration of androgen to castrated animals prevented the post-castration rise in activity of the human or bovine $\alpha$ subunit promoters in pituitaries of transgenic male mice (Fig, 2, Clay et al, 1993). The suppressive effects of dihydrotestosterone (a nonaromatizable androgen) on the expression of the transgene were not as marked as the effects of testosterone (Fig. 2). Suppression of $\alpha$ subunit transgene expression in testosterone-treated transgenic male mice may have resulted from direct effects of androgen (DHT) and indirect effects occurring after aromatization of testosterone to oestrogens (Clay et al, 1993). The ability of the androgen receptor to bind directly to the human $\alpha$ subunit promoter implies that androgen may act directly at the pituitary gland, in addition to acting indirectly at the hypothalamus to inhibit secretion of $\mathrm{GnRH}$, and inhibit expression of the $\alpha$ subunit gene.

In transgenic mice harbouring rat or bovine LHB subunit $5^{\prime}$ flanking sequences, promoter activity was increased after castration and suppressed by chronic administration of androgen to castrate males (Fallest and Shupnik, 1994; Keri et al, 1994). Preliminary evidence (Keri et al., 1994) indicated that the 


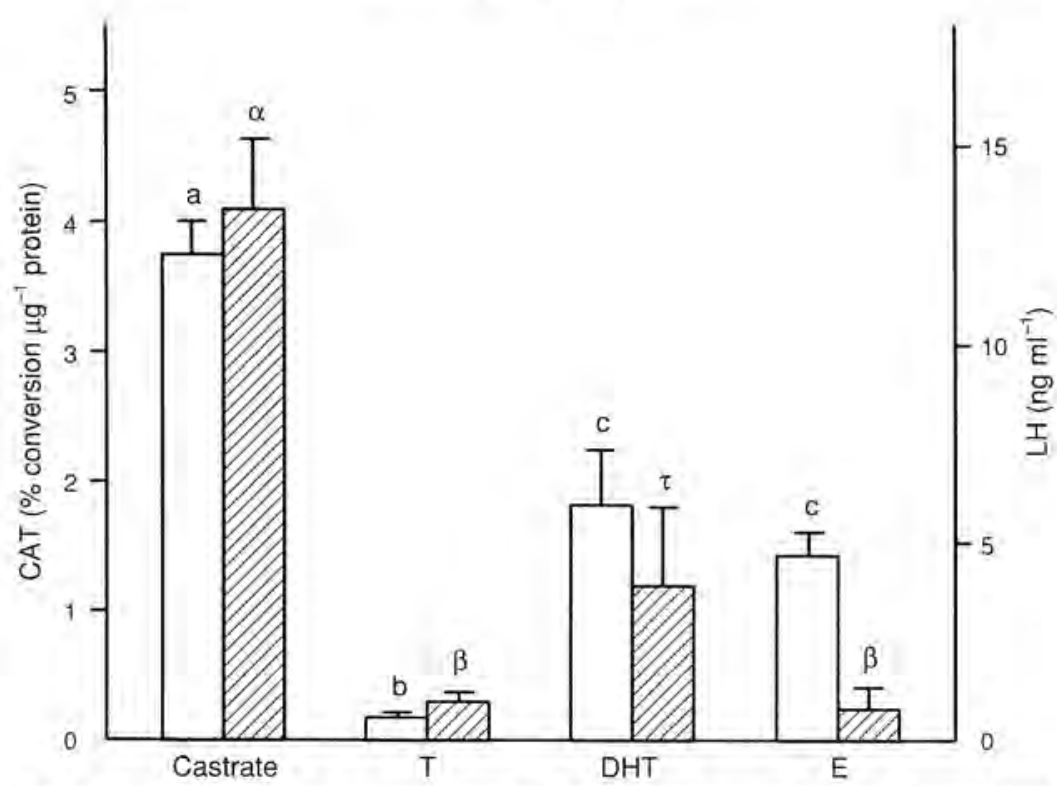

Fig. 2. Oestrogen and androgens suppress the post-castrational rise in chloramphenicol acetyltransferase (CAT) activity in the pituitary $(\square)$ and serum concentrations of $\mathrm{LH}(\mathbb{Z})$ in transgenic mice containing the proximal $315 \mathrm{bp}$ of $5^{\prime}$ flanking sequence of the bovine $\alpha$ subunit gene linked to the bacterial gene encoding CAT. Adult male, transgenic mice were castrated and implanted with constant release pellets containing inert carrier (castrate), testosterone (T), $5 \alpha$-dihydrotestosterone (DHT) or oestradiol (E) for two weeks. Lettered superscripts above vertical bars represent statistical differences in CAT activity. Greek symbols above vertical bars represent statistical differences in serum concentrations of LH. Reprinted from Clay et al. (1993) with permission.

bovine LH $\beta$ subunit $5^{\prime}$ flanking sequence lacked a high-affinity binding site for the androgen receptor; thus, regulation of LH $\beta$ subunit gene expression by androgen probably involves an indirect action of androgens to decrease secretion of GnRH from the hypothalamus.

Chronic administration of androgen to transgenic mice expressing the human FSH $\beta$ subunit gene resulted in profound suppression of human, but lesser suppressive effects on mouse, mRNA encoding FSH $\beta$ subunit in pituitary (Kumar and Low, 1993). Suppresșive effects of androgen on FSH $\beta$ subunit gene expression may have resulted from species differences in FSH $\beta$ subunit gene regulation. It is possible that the rodent FSH $\beta$ subunit gene lacked direct androgen regulatory sequences or that the human FSH $\beta$ subunit gene was more dependent on GnRH stimulation for basal expression than was the mouse FSH $\beta$ subunit gene (Kumar and Low, 1993). Further studies will be needed to understand differential regulation of human, rodent and ruminant FSH $\beta$ subunit genes by androgens more fully.

\section{GnRH-responsive DNA sequences}

Pulsatile GnRH stimulated amounts of gonadotrophin subunit mRNA in rodents and ruminants (Gharib et al., 1990; Mercer, 1990; Nett, 1990). A GnRH responsive region spanning nucleotides -346 to -244 of the human $\alpha$ subunit promoter was identified by transient transfection in $\alpha \mathrm{T} 3-1$ cells (Kay and Jameson, 1992). Nucleotides -416 to -385 of the mouse $\alpha$ subunit promoter were also responsive to GnRH after transient transfection in $\alpha$ T3-I cells (Schoderbek et al, 1993). To determine whether human or bovine $a$ subunit $5^{\prime}$ flanking sequences contained GnRH-responsive regions, we conducted ovariectomy and hormone replacement studies with chronic oestradiol and pulsatile GnRH in transgenic mice (Fig. 3). Pulsatile administration of GnRH in the continued presence of oestradiol completely 


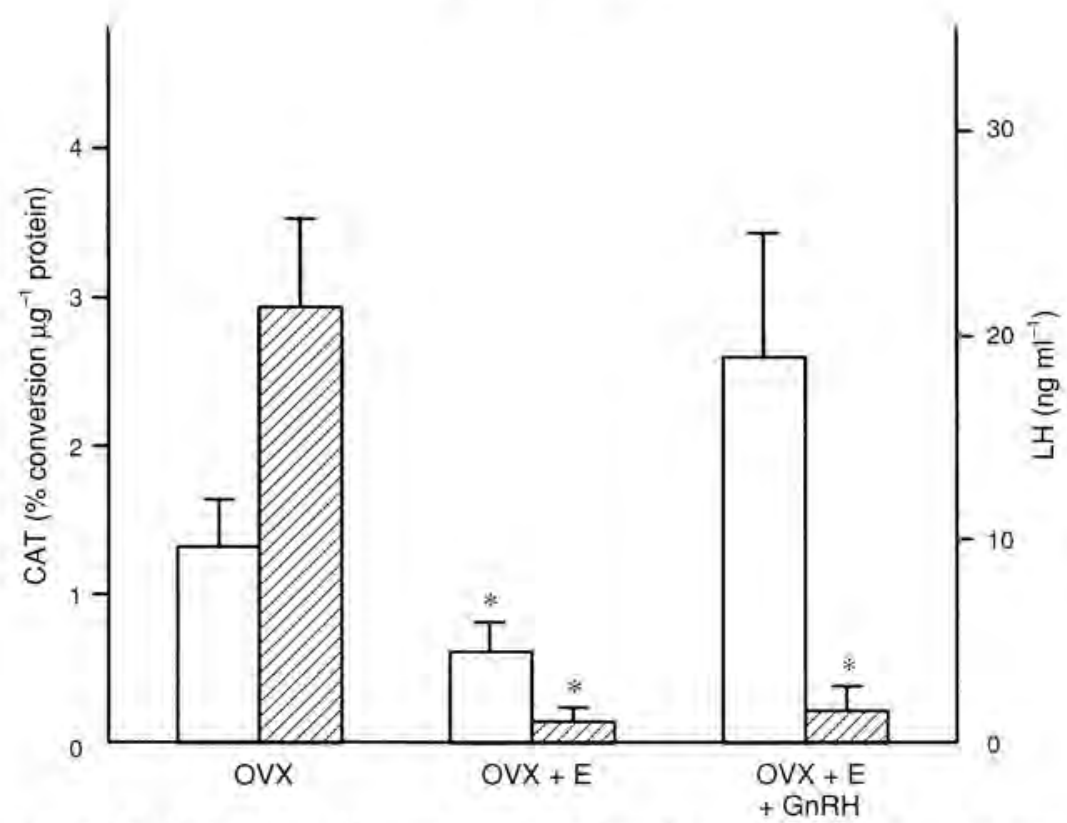

Fig. 3. GnRH stimulates chloramphenicol acetyltransferase (CAT) activity in pituitary of transgenic mice $(\square)$ containing the proximal 315 bp of $5^{\prime}$ flanking sequence of the bovine $\alpha$ subunit gene linked to the bacterial gene encoding CAT. Adult female, transgenic mice were ovariectomized (OVX), treated with daily injections of oestradiol (E) for 14 days $(O V X+E)$, and saline or GnRH every other hour for the last 7 days of oestradiol treatment (OVX $+E+G n R H)$. Serum and pituitaries were collected $30 \mathrm{~min}$ after the last injection of GnRH. (Z) Serum concentrations of LH. *Significantly different from OVX. Reprinted from Hamernik et al. (1992) with permission.

restored activity of the human or bovine $\alpha$ subunit promoters to values similar to those of ovariectomized mice (Hamernik et al, 1992). From these studies, we concluded that the proximal $1500 \mathrm{bp}$ of human or $315 \mathrm{bp}$ of bovine $\alpha$ subunit $5^{\prime}$ flanking sequence contained sufficient information to confer responsiveness to $\mathrm{GnRH}$ in transgenic mice.

Studies with the human and mouse promoters in $\alpha \mathrm{T} 3-1$ cells that identified a GnRH-responsive region upstream of $329 \mathrm{bp}$ are difficult to reconcile with our results demonstrating GnRH responsiveness in transgenic mice containing only 315 bp of the bovine $\alpha$ subunit promoter. It is possible that there are subtle differences between species in nucleotide sequences or that studies with transgenic mice represent a more physiological model to study cell-specific expression and hormonal regulation of gonadotrophin subunit genes because stringent requirements are imposed on DNA sequences to direct correct temporal and spatial expression of the transgene during development. Specific DNA sequences in the $\alpha$ subunit promoter that confer responsiveness to $\mathrm{GnRH}$ in transgenic mice remain to be identified.

What second messenger system mediates $\mathrm{GnRH}$-stimulated transcription of gonadotrophin subunit genes? There is considerable evidence that GnRH-induced secretion of LH involved activation of the calcium or protein kinase C pathways (Conn et al., 1987); however, relatively little is known about the intracellular mediators of GnRH-induced transcription of $\alpha$ subunit. Tandem CRE were found in the human $\alpha$ subunit $5^{\prime}$ flanking sequence and mediated transcriptional induction after activation of the protein kinase A or C pathways in human choriocarcinoma cells (Jameson and Hollenberg, 1993); thus, it is possible that $\mathrm{GnRH}$ activates transcription of the human $\alpha$ subunit promoter through the CRE. The bovine $\alpha$ subunit $5^{\prime}$ flanking region contains a CRE-like sequence that failed to bind CREB and failed to confer cAMP responsiveness after transient transfection in human choriocarcinoma cells (Bokar et al. 1989), yet the bovine $\alpha$ subunit promoter was transcriptionally stimulated by $\mathrm{GnRH}$ in transgenic mice (Hamernik et al, 1992). It seems likely that DNA sequences other than the CRE, but within the proximal 
315 bp of the bovine $\alpha$ subunit promoter, are needed for GnRH-induced transcription of the bovine $\alpha$ subunit gene in transgenic mice. Amounts of mRNA for LHß subunit in rat pituitaries in vitro were stimulated by $\mathrm{GnRH}$ and activation of the protein kinase C pathway (Andrews et al, 1988). In addition, administration of a GnRH antagonist to transgenic mice harbouring the bovine LH $\beta$ subunit gene resulted in decreased activity of the promoter compared with ovariectomized transgenic mice (Keri et al., 1994). The proximal 800 bp of $5^{\prime}$ flanking sequence of the bovine LH $\beta$ subunit gene lacked a consensus CRE but contained enough information to confer responsiveness to GnRH in transgenic mice. Specific DNA sequences and DNA-binding proteins mediating GnRH-stimulated transcription of gonadotrophin $\alpha$ and $\beta$ subunit genes remain to be characterized.

\section{Conclusions}

Transgenic mice and transient transfection assays with mouse gonadotroph cell lines expressing the endogenous mouse $\alpha$ subunit gene have proved valuable in identifying DNA sequences in mouse and human gonadotrophin $\alpha$ subunit genes that direct expression specifically to gonadotrophs and mediate hormone responsiveness. Development of gonadotroph cell lines that express bovine or ovine gonadotrophin $\alpha$ or $\beta$ subunit genes or in vivo gene transfer studies into cattle or sheep will be needed to define further molecular mechanisms that regulate cell-specific expression and hormone responsiveness of bovine or ovine gonadotrophin genes. A better understanding of the molecular mechanisms that regulate synthesis of gonadotrophins may lead to methods to for enhancing reproductive efficiency in domestic animals.

Published as paper No. 10862, Journal Series Nebraska Agricultural Research Division and supported by the Nebraska Agricultural Research Division and the UNL Center for Biotechnology. The author thanks C. Clay, E. Grotjan and J. Kinder for helpful suggestions during preparation of this manuscript. She also thanks J. Nilson, R. Keri, C. Clay and members of the Nilson laboratory for intriguing discussions on the regulation of gonadotrophin gene expression.

\section{References}

Andersen B, Kennedy GC and Nilson JH (1990) A cis-acting element located between the CAMP response elements and CCAAT box augments cell-specific expression of the glycoprotein hormone a subunit gene Joumal of Biological Chemistry 265 21874-21880

Andrews WV, Maurer RA and Conn PM (1988) Stimulation of rat luteinizing hormone- $\beta$ messenger RNA levels by gonadotrophin releasing hormone Joumal of Biological Chemistry $26313755-13761$

Attardi B and Winters SI (1993) Decay of follicle-stimulating hormone- $\beta$ messenger RNA in the presence of transcriptional inhibitors and/or inhibin, activin, or follistatin Molecular Endocrinology $7668-680$

Attardi B, Marshall GR, Zorub DS, Winters SJ, Miklos J and Plant TM (1992) Effects of orchidectomy on gonadotropin and inhibin subunit messenger ribonucleic acids in the pituitary of the thesus monkey (Macaca mulatta) Endocinology 130 1238-1244

Barnhart KM and Mellon PL (1994) The orphan nuclear receptor, steroidogenic factor-1, regulates the glycoprotein hormone $\alpha$-subunit gene in pituitary gonadotropes Molecular Endoctinology 8 878-885

Beard AJ, Savva D, Glencross RG, McLeod BJ and Knight PG (1989) Treatment of ovariectomized heifers with bovine follicular fluid specifically suppresses pituitary levels of FSH- $\beta$ mRNA Journal of Molecular Endocrinology $385-91$
Beato M (1989) Gene regulation by steroid hormones Cell 56 $335-344$

Bilezikjian LM, Vaughan IM and Vale WW (1993) Characterization and the regulation of inhibin/activin subunit proteins of cultured tat anterior pituitary cells Endocrinology 133 2545-2553

Bokar JA, Keri RA, Farmerie TA, Fenstermaker RA, Andersen B, Hamernik DL, Yun J, Wagner T and Nilson JH (1989) Expression of the glycoprotein hormone $\alpha$-subunit gene in the placenta requires a functional cyclic AMP response element, whereas a different cis-acting element mediates pituitary-specific expression Molecular and Cellular Biology 9 5113-5122

Brown P, McNeilly JR, Wallace RM, McNeilly AS and Clark AJ (1993) Characterization of the ovine LHß-subunit gene: the promoter directs gonadotrope-specific expression in transgenic mice Molecular and Cellular Endocrinology 93 $157-165$

Chappel SC, Ulloa-Aguirre A and Coutifaris C (1983) Biosynthesis and secretion of follicle-stimulating hormone Endocrine Reviews 4 179-211

Chatterjee VKK, Lee J-K, Rentoumis A and Jameson JL (1989) Negative regulation of the thyroid-stimulating hormone a gene by thyroid hormone: receptor interaction adjacent to the TATA box Proceedings of the National Academy of Sciences USA $869114-9118$ 
Chedrese PJ, Kay TWH and Jameson JL (1994) Gonadotropinreleasing hormone stimulates glycoprotein hormone $\alpha$-subunit messenger ribonucleic acid (mRNA) levels in aT3 cells by increasing transcription and mRNA stability Endocrinology $134 \quad 2475-2481$

Clarke IJ, Rao A, Fallest PC and Shupnik MA (1993) Transcription rate of the follicle stimulating hormone (FSH) $\beta$ suburit gene is reduced by inhibin in sheep but this does not fully explain the decrease in mRNA Molecular and Cellular Endocrinology 91 211-216

Clay CM, Keri RA, Finicle AB, Heckert LL, Hamernik DL, Marschke KM, Wilson EM. French FS and Nilson JH (1993) Transcriptional repression of the glycoprotein hormone $\alpha$ subunit gene by androgen may involve direct binding of androgen receptor to the proximal promoter Journal of Biological Chemistry 268 13556-13564

Conn PM, McArdle CA, Andrews WV and Huckle WR (1987) The molecular bias of gonadotropin-releasing hormone $(\mathrm{GnRH})$ action in the pituitary gonadotrope Biology of Reproduction 36 17-35

DePaolo LV, Mercado M, Guo Y and Ling N (1993) Increased follistatin (activin-binding protein) gene expression in rat anterior pituitary tissue after ovariectomy may be mediated by pituitary activin Endocrimology $1322221-2228$

Fallest PC and Shupnik MA (1994) Gonadal steroid feedback regulation of rat luteinizing hormone $\beta$ gene expression in transgenic mice Biology of Reproduction $\mathbf{5 0}$ (Supplement 1) 149

Findlay JK (1993) An update on the roles of inhibin, activin, and follistatin as local regulators of folliculogenesis Biology of Reproduction 48 15-23.

Gharib SD, Wierman ME, Shupnik MA and Chin WW (1990) Molecular biology of the pituitary gonadotropins Endocrine Reviews 11 177-199

Hamernik DL. Crowder ME, Nilson JH and Nett TM (1986) Measurement of messenger ribonucleic acid for luteinizing hormone $\beta$-subunit, $\alpha$-subunit, growth hormone, and prolactin following hypothalamic-pituitary disconnection in ovariectornized ewes Endocrinology 119 2704-2710

Hamernik DL. Keri RA. Clay CM, Clay IN, Sherman GB, Sawyer HR, Jr, Nett TM and Nilson JH (1992) Gonadotrope-and thyrotrope-specific expression of the human and bovine glycoprotein hormone $\alpha$-subunit genes is regulated by distinct cis-acting elements Molecular Endocrinology 6 1745-1755

Horn F, Windle J. Barnhart KM and Mellon PL (1992) Tissuespecific gene expression in the pituitary: the glycoprotein hormone $\alpha$-subunit gene is regulated by a gonadotropespecific protein Molecular and Cellular Biology 12 21432153

Jameson JL and Hollenberg AN (1993) Regulation of chotionic gonadotropin gene expression Endocrine Reviews 14 203-221

Karsch F], Cummins JT, Thomas GB and Clarke II (1987) Steroid feedback inhibition of pulsatile secretion of gonadotropinreleasing hormone in the ewe Biology of Reproduction 36 1207-1218

Kay TWH and Jameson JL (1992) Identification of a gonadotropin-releasing hormone-responsive region in the glycoprotein hormone $\alpha$-subunit promoter Molecular Endocrinology 6 1767-1773

Kendall SK, Saunders $\mathrm{TL}_{\ell}$ Jin L, Lloyd RV, Glode LM, Nett TM, Keri RA, Nilson JH and Camper SA (J991) Targeted ablation of pituitary gonadotropes in transgenic mice Molecular Endocrinology 5 2025-2036
Kennedy GC, Anderson B and Nilson JH (1990) The human $\alpha$ subunit glycoprotein hormone gene utilizes a unique CCAAT binding factor Journal of Biological Chemistry 265 6279-6285

Keri RA, Anderson B, Kennedy GC, Hamernik DL, Clay CM, Brace AD, Nett TM. Notides AC and Nilson JH (I991) Estradiol inhibits transcrition of the human glycoprotein hormone a-subunit gene despite the absence of a high affinity binding site for the estrogen receptor Molecular Endocrinology 5 725-733

Keri RA, Wolfe MW, Kendall SK, Saunders TL, Camper SA, Nett TM and Nilson JH (1994) Gonadotrope-specific expression and hormonal regulation of the bovine LH $\beta$ subunit gene promoter in transgenic mice 76 th Anmal Meeting of the Endocrine Society, Amaheim, CA p 503

Kim KE, Day KH, Howeard P, Salton SRJ, Roberts JL and Maurer RA (1990) DNA sequences required for expression of the LH $\beta$-subunit promoter in primary cultures of rat pituitary cells Molecular and Cellular Endocrinology 74 101-107

Kumar TR and Low MJ (1993) Gonadal steroid hormone regulation of human and mouse follicle stimulating hormone $\beta$-subunit gene expression in vivo Molecular Endocrinology 7 898-906

Markkula MA, Hamalainen TM, Zhang F, Kim KE, Maurer RA and Huhtaniemi IT (1993) The FSH $\beta$-subunit promoter directs the expression of Herpes simplex virus type 1 thymidine kiriase to the testis of transgenic mice Molecular and Cellular Endocrinology 96 25-36

Mercer IE (1990) Pituitary gonadotropin gene regulation Molecular and Celludar Endocrinology 73 C63-C67

Mercer JE, Clements JA, Funder JW and Clarke IJ (1987) Rapid and specific lowering of pituitary FSH 3 mRNA levels by inhibin Molecular and Cellular Endocrinology $\mathbf{5 3}$ 251-254

Mercer JE, Clements JA, Funder JW and Clarke IJ (1988) Luteinizing hormone- $\beta$ mRNA levels are regulated primarily by gonadotrophin-releasing hormone and not by negative estrogen feedback on the pituitary Neuroendocrinology 47 563-566

Mercer JE, Clements JA, Funder JW and Clarke IJ (1989) Regulation of follicle-stimulating hormone $\beta$ and common Q-subunit messenger ribonucleic acid by gonadotropinreleasing hormone and estrogen in the sheep pituitary Neuroendocrinology $50321-326$

Nett TM (1990) Regulation of genes controlling gonadotropin sceretion Jotinal of Animal Science 68 (Supplement 2) 3-17

Nett TM, Flores JA, Carnevali F and Kile JP (1990) Evidence for a direct negative effect of estradiol at the level of the pituitary gland in sheep Biology of Reproduction 43 $554-558$

Ocran KW, Sarapura VD, Wood WW, Gordon DF, GutierrezHartmann A and Ridgway EC (1990) Identification of cis-acting promoter elements important for expression of the mouse glycoprotein hormone $\alpha$-subunit gene in thyrotropes Molecular Endocrinology 4 766-772

Paul SJ, Ortolano GA, Haisenleder DJ, Stewart JM, Shupnik MA and Marshall JC (1990) Gonadotropin subunit messenger RNA concentrations after blockade of gonadotropinreleasing hormone action: testosterone selectively increases follicle-stimulating hormone $\beta$-subunit messenger RNA by posttranscriptional mechanisms. Molecular Endocrinology 5 1943-1955

Phillips CL, Lin L-W, Wu JC, Guzman K, Milsted A and Miller WL (1988) $17 \beta$-Estradiol and progesterone inhibit transcription 
of the genes encoding the subunits of ovine folliclestimulating hormone Molecular Endocrinology 2 641649

Pierce JG and Parsons RF (1981) Glycoprotein homones: structure and function Annual Review of Biochemistry $\mathbf{5 0}$ 465-495

Pittman RH, Clay CM, Farmerie TA and Nilson JH (1994) Functional analysis of the placenta-specific enhancer of the human glycoprotein hormone a subunit gene Journal of Biological Chemistry $26919360-19368$

Roberson MS, Wolfe MW, Stumpf TT, Hamernik DL, Cupp AS, Werth LA, Kojima N, Kittok RJ, Grotjan HE and Kinder JE (1992) Steady-state amounts of $\alpha$-and luteinizing hormone (LH) $\beta$-subunit messenger ribonucleic acids are uncoupled from pulsatility of $\mathrm{LH}$ secretion during sexual maturation of the heifer Biology of Reproduction 46 435-441

Roberson MS, Schoderbek WE, Tremml G and Maurer RA (1994) Activation of the glycoprotein hormone $\alpha$-subunit promoter by a LIM-homeodomain transcription factor Molecular and Cellular Biology 14 2985-2993

Roberts V, Meunier H, Vaughan J, Rivier J, Rivier C, Vale W and Sawchenko P (1989) Production and regulation of inhibin subunits in pituitary gonadotropes Endocrinology $124552-554$

Sanchez T, Wehrman ME, Moss GE, Kojima FN, Cupp AS, Bergfeld EG, Peters KE, Mariscal V, Grotjan HE Jr, Kinder JE and Hamernik DL (1994) Differential regulation of gonadotropin synthesis and release in ovariectomized ewes after treatment with a luteinizing hormone-releasing hormone antagonist Biology of Reproduction 51 755-759

Sarapura VC, Wood WM, Gordon DF, Ocran KW, Kao MY and Ridgway EC (1990) Thyrotrope expression and thyroid hormone inhibition map to different regions of the mouse glycoprotein hormone $\alpha$-subunit gene promoter Endocrinologv 127 1352-136́1
Schoderbek WE, Kim KE, Ridgway EC, Mellon PL and Maurer RA (1992) Analysis of DNA sequences required for pituitaryspecific expression of the glycoprotein hormone $\alpha$-subunit gene Molecular Endocrinology $6893-903$

Schoderbeck WE, Roberson MS and Maurer RA (1993) Two different DNA elements mediate gonadotropin releasing hormone effects on expression of the glycoprotein hormone $\alpha$-subunit gene Joumal of Biological Chemistry 268 3903-3910

Shupnik WA, Weinmann CM, Notides AC and Chin WW (1989) An upstream region of the rat luteinizing hormone $\beta$ gene binds estrogen receptor and confers estrogen responsiveness Journal of Biological Chemistry 264 80-86

Steger DJ, Buscher M, Hecht JH and Mellon PL (1993) Coordinate control of the $\alpha$-and $\beta$-suburit genes of human chorionic gonadotropin by trophoblast-specific elementbinding protein Molecular Endocrinology 7 1579-1588

Steger DJ, Hecht JH and Mellon PL (1994) GATA-binding proteins regulate the human gonadotropin $\alpha$-subunit gene in the placenta and pituitary gland Molecular and Cellular Biology $145592-5002$

Stumpf RR, Wolfe MW, Roberson MS, Caddy G, Kittok RJ, Schanbacher BD, Grotjan HE and Kinder JE (1992) Bovine luteinizing hormone (LH) isoforms and amounts of messenget ribonucleic acid for alpha- and LH beta-subunits in pituitaries of cows immunized against LH-releasing hormone Biology of Reproduction 47 776-781

Wierman ME and Wang C (1990) Androgen selectively stimulates follice-stimulating hormone-ß3mRNA levels after gonadotropin-releasing hormone antagonist administration Biology of Reproduction 42 563-57I

Windle J], Weiner RI and Mellon PL (1990) Cell lines of the pituitary gonadotrope lineage derived by targeted oncogenesis in transgenú mice Molecular Endocrinology 4 $597-603$ 